\title{
Environmental challenges in Nepal and actions to address
}

\section{Proceeding}

After completion of my graduate exam, I went to Gorkha which is most affected district by the last year earthquake for implementation of one project funded by Habitat for Humanity. When I reached there I was dismayed by the condition of the people. They don't have house to stay and enough food to eat. The field was barren without any vegetation and all the natural water sources were dry as there was no rainfall. So, most people were migrating to terai for survival which has caused land fragmentation and degradation in terai. In other side remaining people were in plan of constructing new houses and all the villagers were busy in cutting trees. Now I heard the news that there is landslide and food shortage in that village. There is heavy rainfall and landslide in the same place where there was no rainfall for cultivation of crops. This is due to climate change which is result of deforestation, unplanned urbanization, pollution, population growth and poverty. Climate change itself is not a big problem but its consequences like erratic rainfall, agro biodiversity loss, incidence of new diseases and natural disaster are causing greater loss. Therefore poverty, deforestation, pollution and rapid population growth are major environmental challenges of Nepal.

Size of absolute population has increased considerably. If the present trend continues it is likely that natural resources will be depleted at an unprecedented rate. Population growth has both, positive and negative implications in resource conservation and use. But in case of Nepal negative implication are more than positive. Rapid population growth has caused environmental problems like deforestation, over cultivation and land degradation. Population growth has a constant pressure on natural resource base such as forests, water and land. Poverty is both cause and effect of environmental degradation. Many international reports claim that poverty is a major cause of environmental degradation, including the World Commission on Environment and Development's report. Poverty forces one to venture into more extensive agriculture by clearing marginal land for cultivation. Poor people have low education and awareness level that leads to the widespread of garbage. In addition, they use firewood as main source of fuel which increases deforestation. Our forests are natural sinks of carbon dioxide and produce fresh oxygen as well as helps in regulating temperature and rainfall. Due to growing population demand for more food, shelter and cloth tree cutting is increasing day by day. The main reason behind deforestation in Nepal is high number of landless people. People are converting fertile and cultivable land to residential area as result there is biodiversity loss. So, land fragmentation is also a major environmental challenge for Nepal.

Generally urban pollution is main challenge to environment in Nepal than rural pollution. Industrial emission, vehicle emission, city waste and garbage, high level of construction etc. contributes tremendously to the pollution. The garbage and emission from the industry, city and vehicle are degrading environment. But being agriculturist I also see Agriculture pollution as promising challenge to environment. It is caused intense use of fertilizer and pesticides in field.

\author{
Volume 8 Issue 5 - 2018
}

\section{Suresh Simkhada}

Post Graduate student of Agribusiness Management at

Agriculture and Forestry University, Nepal

Correspondence: Suresh Simkhada, Post Graduate student of Agribusiness Management at Agriculture and Forestry University, Nepal, Email cmkhadasurace@gmail.com

Received: January 30, 2017| Published: October 04, 2018

Following actions and intervention can be useful for addressing above environmental challenges in sustainable way.

Education and awareness creation against the environment degradation and population growth as it is main factor for environment degradation:

1. Internalization of the Environmental Impact Assessment (EIA) system particularly in development plan and programs.

2. Economic instruments like subsidies on biogas plants in the rural areas are likely to have positive impacts on the environment.

3. Provide additional concession and facilities to industries and enterprises to encourage sustainable level of consumption and adopt cleaner technologies and processes which cause positive impacts on the environment.

4. Controlling numbers of vehicles entry each year in the municipalities and color rating system of vehicles in terms of environmental health system.

5. Promotion of the use of low-polluting means of transport and environment-friendly fuel.

6. Development of integrated settlements for rural and marginalized areas and endangered groups to balance the regional distribution of population and control land degradation.

7. Restriction of unauthorized, uncontrolled and unorganized urbanization and settlement development process.

8. Contribution towards poverty alleviation by intensifying income generation.

9. Mobilization of youth-power, capitalizing on the demographic dividend, in national development by engaging youths in creative and productive activities etc.

Besides all these, if the present trend of population growth is not controlled, poverty is not alleviated, political commitment is not ensured and if the continuation of the existing consumption pattern and resource constraints remain the same, environmental degradation are likely to continue in future too.

Therefore, holistic integrated environmental management (IEM) approach is needed to arrest environmental degradation and increase 
national productivity. Implementation of this approach would promote ecosystem-based participatory management of natural resources and address environmental pollution through a mix of command and control (CAC) and non-regulatory market based incentive measures. A sustainable society could thus be achieved.

\section{Acknowledgements}

None.

\section{Conflict of interest}

The author declares there is no conflict of interest. 